UDC 616-006.441

\title{
Efficiency of application of different DNA probes in identifying marker chromosomes
}

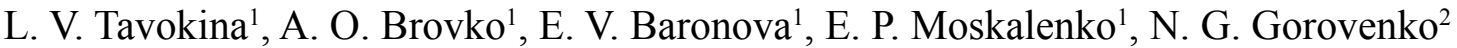 \\ ${ }^{1}$ Medical centre "ISIDA-IVF", laboratory of molecular cytogenetics. \\ bulvar Ivana Lepse 65, Kyiv, Ukraine. \\ ${ }^{2}$ Shupyk National Medical Academy of Postgraduate Education. Department of medical and laboratory genetics. \\ Str. Dorohozhytska 9, Kyiv, Ukraine. \\ L_Tavokina@isida.ua;medgen2006@mail.ru
}

\begin{abstract}
The presence of marker chromosomes in the human karyotype always requires a special diagnostic approach. Determination of the marker chromosome type and structure is of great diagnostic and prognostic importance. There are several methods of marker chromosomes identification, which differ in their informative value. The paper presents the results of cytogenetic and FISH diagnostics of supernumerical marker chromosomes (SMC) in patients' karyotype. Aim. To analyze the results of the cytogenetic and molecular cytogenetic diagnostics for patients with marker chromosomes, and to evaluate and compare the efficiency of the methods used. Methods. Karyotyping was done according to the standard methods. GTG, CBG, QFQ and NOR-Ag methods of differential staining were used. FISH was performed according to the manufacturer's instructions for CEP, LSI and WCP DNA-probes. Results. Marker chromosome was found in 15 of 7989 patients. Application of standard staining methods was effective in $66.6 \%$ of cases. Combination of differential staining and FISH allowed identifying a marker chromosome in $83.3 \% .90 \%$ of all marker chromosomes were identified as isochromosomes and $60 \%$ of them were derivative from chromosome 15. Conclusions. The use of WCP probes is a main step in the marker chromosome identification with further application of CEP/LSI probes. If a marker chromosome has nonspecific DNA sequences more sensitive methods should be used.
\end{abstract}

Keywords: molecular cytogenetic diagnostics, marker chromosome, DNA probes

The overall frequency distribution of supernumerical marker chromosomes (SMC) ranges from 0.65 to 1.5 in 1000 according to the published data [1]. The risk of having a child with abnormalities for the carriers of marker chromosomes depends on the group of chromosomes involved in the SMC formation, cellular mosaicism, and the euchromatin sequences presence. The most common SMC arise from acrocentric chromosomes (about $80 \%$ ), about $60 \%$ of which are chromosome 15 derivatives [2]. The study was aimed at comparing and evaluating several classical cytogenetics and fluorescence in situ hybridiza- tion (FISH) methods of identifying the small supernumerical marker chromosomes.

\section{Materials and Methods}

\section{Cultivation methods}

Cytogenetic diagnosis was performed on the metaphase chromosomes samples of human peripheral blood lymphocytes. Cultivation of lymphocytes was carried out by the semi-micro method followed by application of metaphase chromosomes preparation standard protocols [3]. $5 \mathrm{ml}$ of RPMI cell culture

(C) 2016 L.V. Tavokina et al.; Published by the Institute of Molecular Biology and Genetics, NAS of Ukraine on behalf of Biopolymers and Cell. This is an Open Access article distributed under the terms of the Creative Commons Attribution License (http://creativecommons.org/licenses/by/4.0/), which permits unrestricted reuse, distribution, and reproduction in any medium, provided the original work is properly cited 
media (Gibco, USA) were used for the human peripheral blood lymphocytes cultivation. The phytohemaglutinin (Gibco, USA) was added to induce lymphocytes mitotic activity. After 72 hours, colcemid (Gibco, USA) was added to the culture to stop mitosis at the metaphase stage. Hypotonic treatment of the sample was carried out using $0.075 \mathrm{M} \mathrm{KCl}$. The cell suspensions were fixed by adding ethanolacetic acid $(3: 1 \mathrm{v} / \mathrm{v})$.

\section{Staining method}

A number of differential staining techniques were used for cytogenetic analysis of lymphocyte metaphase plates: GTG (G-bands by trypsin using Giemsa), CBG (C-bands by barium hydroxide using Giemsa), QFQ (Q-bands by fluorescence using quinacrine), NOR -Ag (Nuclear Organizer Region staining by $\mathrm{AgNo}_{3}$ ) [4]. The coding system consists of three letters, and usually includes the main method of painting, chromosome pretreatment agent and name of the dye. The structures motifs along the chromosomes are called G-, C-, Q- bands according to the type of staining. GTG staining results in dark bands which correspond to heterochromatin and light bands consisting of euchromatin. G-bands have brighter fluorescence in QFQ method of staining. CBG technique allows detecting constitutional chromosome centromeric heterochromatin by saturated barium hydroxide solution pretreatment followed by incubation in $2 \mathrm{xSSC} 60^{\circ} \mathrm{C}$ buffer with Giemsa dye staining. CBG stained chromosomes look very pale. Centromeric heterochromatin is built of repetitive DNA sequences and forms the so-called satellite DNA which is intensely colorized. NOR-Ag is used to identify satellites on the short arm of acrocentric human chromosomes (13, $14,15,21,22)$.

\section{Fluorescence in situ hybridization}

FISH was performed according to the manufacturer's instructions using DNA probes for specific parts of chromosomes: CEP (Chromosome Enumeration Probe, Abbot, USA) - centromeric probes, LSI (Locus Specific Identifier, Abbot, USA) - locus spe- cific probes and WCP (Whole Cromosome Painting CytoCell, UK) probes.

\section{Interpretation and analyzing}

A CytoVision software (Applied Imaging, USA) was used to analyze chromosomes and hybridization signals. Interpretation of karyotypes was done in accordance with the international classification system of human chromosomes ISCN 2013 (International System for Human Cytogenetic Nomenclature 2013) [5]

\section{Results and Discussion}

7989 patients had been tested during the period from 2012 to 2015 . SMC were found in 15 patients. The rate of 1.8 per 1,000 cases is consistent with the literature [6]. 7 of these karyotypes were mosaic $(53 \%)$ and SMC were detected in 3 children aged from 1 to 3 years who underwent cytogenetic diagnostics with indications: delayed physical and mental development, muscle hypotonia, embryogenesis stigmas.

To clarify the composition and origin of SMC, an additional methods CBG, QFQ, NOR-Ag and FISH were applied after identifying marker chromosome by GTG.

Use of CBG, QFQ, NOR-Ag was justified in 10 cases $(66.6 \%)$ whereas 5 cases $(33.3 \%)$ did not give positive results. The panels of LSI and CEP DNA probes were used in 12 cases on the basis of the preliminary results of GTG, CBG, QFQ, NOR-Ag staining. This combination of techniques allowed determining the nature of SMC in 10 patients $(83.3 \%)$. Identification of a marker chromosome by FISH using CEP, LSI and WCP probes failed in two cases. For 3 patients FISH was not performed due to the lack of the necessary amount of material.

WCP probes were used to confirm the positive results obtained by FISH with CEP and LSI probes in 4 cases. The results of the WCP study have matched with the previously obtained results of FISH with CEP and LSI probes: the origin of SMC was confirmed in 2 cases whereas in 2 cases the SMC origin remained undefined. A cross-hybridization between 


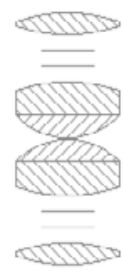

1. $\mathrm{i} 15$

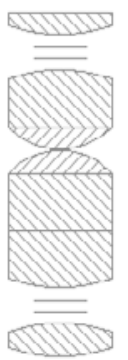

psu idic15

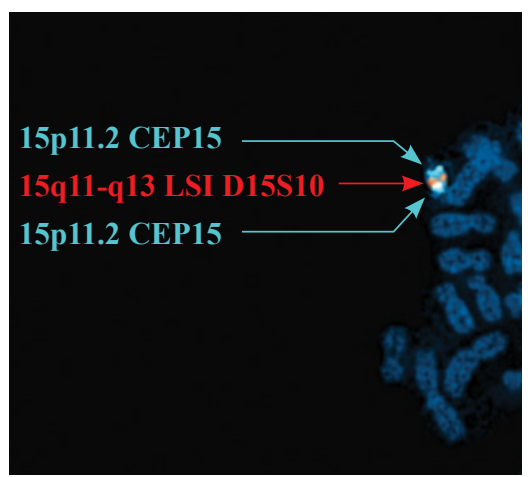

3.

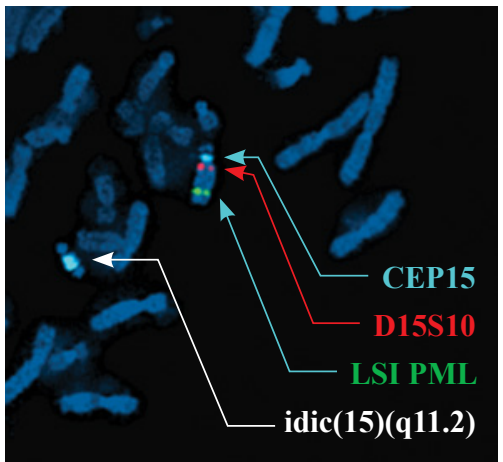

Fig. 1. Idiograms and images of identified marker chromosomes derived from chromosome 15. (1. Idiogram of isochromosome 15, and pseudoisochromosome 15. 2. Pseudoisodicentric chromosome 15 identified by CEP 15 and LSI D15S10. 3. Isodicentric chromosome 15 identified by CEP 15.)

SMC and short arms of D and G chromosome groups was observed. This indicates nonspecific heterochromatin sequences in the SMC composition.

Morphologically isochromosomes accounted for $90 \%$ of all identified SMC. 2 of them (20\%) were identified as pseudoisodicentric marker chromosome (Fig. 1).

In $6(60 \%)$ of the identified SMC cases the revealed marker chromosome was derived from chromosome 15 and in $4(40 \%)$ cases SMC were defined as the derivative of chromosome Y (Fig. 2) (Tab.1).

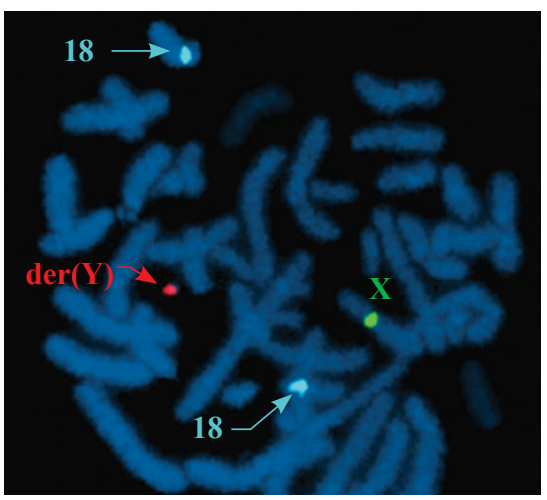

Fig. 2. Identified by CEP Y marker chromosome derived from $\mathrm{Y}$ chromosome.

Table 1. Identification of supernumerical marker chromosomes in karyotypes of patients.

\begin{tabular}{|c|c|c|c|c|c|}
\hline \# & karyotype & $\begin{array}{c}\text { Method and result } \\
\text { (“+”" positive, "-“" negative) }\end{array}$ & $\begin{array}{l}\text { FISH CEP/LSI } \\
\text { and result } \\
\text { (“+”” positive } \\
\text { “_"“negative) }\end{array}$ & $\begin{array}{l}\text { FISH WCP } \\
\text { and result } \\
\text { (“+”” positive } \\
\text { “_“" negative) }\end{array}$ & $\begin{array}{l}\text { Result of SMCs } \\
\text { identification } \\
\text { (“+”” positive } \\
\text { “_"“negative) }\end{array}$ \\
\hline 1 & $\operatorname{mos} 47, \mathrm{XY},+\operatorname{mar}[23] / 46, \mathrm{XY}[7]$ & GTG,+ NOR-Ag + & CEP/LSI 15 - & $\mathrm{WCP}-$ & - \\
\hline 2 & $47, \mathrm{XX},+\mathrm{i}(15)(\mathrm{p} 10)$ & GTG,+ NOR-Ag + & CEP/LSI $15+$ & & + \\
\hline 3 & $47, \mathrm{XY},+\mathrm{i}(15)(\mathrm{p} 10)$ & GTG,+ NOR-Ag+ & CEP/LSI $15+$ & $\mathrm{WCP}+$ & + \\
\hline 4 & 47,XY,+mar.ish psu idic(15) & GTG,+ NOR-Ag+ & CEP/LSI 15+ & & + \\
\hline 5 & 47,XX,+psu idic(15) & GTG,+ NOR-Ag+ & CEP/LSI $15+$ & $\mathrm{WCP}+$ & + \\
\hline 6 & 47,XX,+idic(15)(q11.2) & GTG,+ NOR-Ag + & CEP/LSI $15+$ & & + \\
\hline 7 & $45, X[93] / 46, X, \operatorname{idic}(Y)[7]$ & $\mathrm{GTG}^{+}, \mathrm{QFQ}^{+}$ & CEP Y + & & + \\
\hline 8 & 47,XY,+mar.ish psu idic (15) & GTG + NOR-Ag+ & CEP/LSI $15+$ & & + \\
\hline 9 & $\operatorname{mos} 45, \mathrm{X}[9] / 46, \mathrm{Xidic}(\mathrm{Yq})[13]$ & $\mathrm{GTG}+\mathrm{QFQ}+$ & CEP Y + & & + \\
\hline 10 & $\operatorname{mos} 45, X[14] / 46, X, p s u \operatorname{idic}(Y)(q 11.23)[30]$ & GTG+ QFQ+ & CEP Y+ & & + \\
\hline 11 & $\operatorname{mos} 47, \mathrm{XY},+\operatorname{mar}[18] / 46, \mathrm{XY}[23]$ & GTG + NOR-Ag- & & & - \\
\hline 12 & $\operatorname{mos} 47, \mathrm{XY},+\operatorname{mar}[35] / 46, \mathrm{XY}[5]$ & GTG+ NOR-Ag- & FISH - & WCP- & - \\
\hline 13 & $\operatorname{mos} 47, \mathrm{XY},+\operatorname{mar}[12] / 46, \mathrm{XY}[18]$ & GTG + NOR-Ag- & & & - \\
\hline 14 & $\operatorname{mos} 46, \mathrm{X},+$ mar. ish $\operatorname{der}(\mathrm{Y})[83] / 45, \mathrm{X}[17]$ & GTG+ CBG- QFQ- & CEP Y + & & + \\
\hline 15 & $46, \mathrm{X}, \operatorname{del}(\mathrm{Y})(\mathrm{q} 11.23)$ or $\mathrm{i}(\mathrm{Y})(\mathrm{p} 10)$ & GTG+ QFQ- NOR-Ag- & & & - \\
\hline
\end{tabular}


In most cases identified isodicentric chromosomes consisted of two copies of the chromosome 15 short arm, which were in inverted orientation, marked as «inv dup (15)». Detailed analysis of inv dup (15) showed that this type of SMC usually kept two centromeres one of which was inactive [7]. In some cases, the material between two centromeres contained chromosome 15 euchromatin of various lengths. In 5 patients there were no euchromatin areas between the two centromeres according to FISH results.

As have been previously shown [8], the clinical manifestation of SMC derived from the chromosome 15 presence in karyotype may be associated with four phenotypes: normal phenotype, syndrome inv dup (15) and Prader-Willi/Anhelman syndrome.

Therefore, the presence of SMC in patient's karyotype is a serious indication for the whole family examination:

- to identify SMC by aforementioned methods and if necessary, more sensitive methods like $\mathrm{CGH}$ (Comparative Genomic Hybridization, array CGH, chromosome microdissection and rFISH etc.);

- to determine the fact of SMC inheritance or the occurrence of SMC de novo;

- to exclude tissue mosaicism and uniparental disomy [9];

- family genetic counseling, especially for the carriers of SMCs who are treated by assisted reproductive technologies.

\section{Conclusions}

The methods of differential chromosome staining such as GTG, CBG, QFQ, NORD-Ag are the first and the most important step in the diagnosis of SMC cases.

The results of initial study determine the course of the further analysis. In the case if SMC are supernumerical isochromosomes, or when the Y chromosome normal copy is absent, it is advised to use at first the CEP 15 and CEP Y DNA probes, which identify SMC with efficiency of $83.3 \%$.

The WCP probes may be applied either immediately after GTG analysis, or when the CEP FISH tests do not show positive results. If SMC consist of nonspecific sequences of heterochromatin, applying the WCP probes will be ineffective. The more sensitive methods like CGH/arrayCGH should be recommended in such cases.

\section{REFERENCES}

1. Rubtsov NB, Karamysheva TV, Gayner TA. Supernumerical marker chromosomes. Med Genet. 2003; 2(6):248-58.

2. Van Der Smagt JJ, Giltay JC, De Ne JJ, Slabbers GH. Large inv dup(15) chromosome in two generations. J Med Genet. 1996;33(3):261-2.

3. Baranov V, Kuznetsova T. Cytogenetics of human embryonic development: theoretical and practical aspects. Saint Patersburg: N-L, 2007. 490-1 p.

4. Kuznetsova T, Kuznetsov T, Loginova Y, Chiryaeva O, Pendina A, Baranov $V$. Medical Laboratory Technology: A handbook. Medical laboratory technology. Saint Patersburg: Intermedika, 1998; 550-71 p.

5. ISCN 2013 an international system for human cytogenetic nomenclature (2013). Eds. Shaffer LG, McGowan-Jordan J, Schmid M. Basel: Karger, 2013; 140 p.

6. Dennis N, Hulten M. Idic15. Rare Chromosome Disorder Support Group. Oxted, Unique, 2004.

7. Ewers E, Yoda K, Hamid AB, Weise A, Manvelyan M, Liehr T. Centromere activity in dicentric small supernumerary marker chromosomes. Chromosome Res. 2010;18(5):555-62.

8. Tavokina LV, Brovko AA, Afanasyeva NA, Baronova EV, Moskalenko EP. [Molecular cytogenetic diagnosis of cases with supernumerary marker chromosomes derived from chromosome 15]. Arch Clin Exp Med. 2012; 21(2):190-2.

9. Liehr T, Ewers E, Hamid AB, Kosyakova N, Voigt M, Weise $A$, Manvelyan $M$. Small supernumerary marker chromosomes and uniparental disomy have a story to tell. $J$ Histochem Cytochem. 2011;59(9):842-8.

Ефективність застосування різних типів ДНК-проб для ідентифікації маркерних хромосом.

Л. В. Тавокіна, А. О. Бровко, О. В. Баронова, О. П. Москаленко, Н. Г. Горовенко.

Наявність маркерних хромосом в каріотипі людини завжди вимагає особливого діагностичного підходу. Визначення типу i структури маркерної хромосоми має велике діагностичне і прогностичне значення. Існує кілька методів ідентифікації маркерних хромосом, але різні методи мають різний рівень інформативності. В роботі наведені результати цитогенетичної та FISH діагностики випадків із надчисельними маркерними хромосомами в каріотипі пацієнтів. Мета. Аналіз результатів цитогенетичних i молекулярно-цитогенетичних досліджень каріотипів пацієнтів 3 маркерними хромосомами, а також оцін- 
ка і порівняння ефективності використаних методів. Методи. Каріотипування було виконано у відповідності до стандартних методів. Були використані GTG, CBG, QFQ i NOR-Ag методи диференціального фарбування. FISH була виконана відповідно до інструкцій виробника для CEP, LSI та WCP ДНК-проб. Результати. Маркерна хромосома була виявлена у 15 з 7989 пацієнтів. Застосування стандартних методів фарбування було ефективним у 66,6\% випадків. Поєднання диференціального фарбування та FISH дозволило ідентифікувати маркерні хромосоми у 83,3 \%. 90 \% всіх маркерних хромосом були визначені як ізохромосоми і 60 \% 3 них були похідними від хромосоми 15. Висновки. Використання WСР ДНК-проб є основним етапом ідентифікації маркерних хромосом 3 наступним застосуванням CEP та LSI ДНК-проб. Якщо маркерна хромосома має неспецифічні послідовності ДНК, то у таких випадках повинні бути застосовані більш чутливі методи.

Кл юч о в і с л о в а: молекулярно-цитогенетична діагностика, маркерна хромосома, ДНК-проби

\section{Эффективность применения различных типов ДНК- проба для идентификации маркерных хромосом.}

Л. В. Тавокина, А. А. Бровко, Е. В. Баронова, Е. П. Москаленко, Н. Г. Горовенко.

Наличие маркерных хромосом в кариотипе человека всегда требует особого диагностического подхода. Определение типа и структуры маркерной хромосомы имеет большое диагностическое и прогностическое значение. Существует несколько методов идентификации маркерных хромосом, но разные методы имеют разный уровень информативности. В работе приведены результаты цитогенетической и FISH диагностики случаев со сверхчисленными маркерными хромосомами в кариотипе пациентов. Цель. Анализ результатов цитогенетических и молекулярно-цитогенетических исследований кариотипов пациентов с маркерным хромосомами, а также оценка и сравнение эффективности использованных методов. Методы. Кариотипирование выполнено согласно стандартных методик. Использованы GTG, CBG, QFQ и NOR-Ag методы дифференциального окрашивания. FISH выполнена в соответствии с инструкциями производителя для CEP, LSI и WCP ДНК-проб. Результаты. Маркерная хромосома обнаружена у 15 из 7989 пациентов. Применение стандартных методов окрашивания было эффективным в 66,6 \% случаев. Сочетание дифференциального окрашивания и FISH позволило идентифицировать маркерные хромосомы в 83,3 \%. 90 \% всех маркерных хромосом были определены как изохромосомы и 60 \% из них были производными от хромосомы 15. Выводы. Использование WСР ДНК-проб является основным этапом идентификации маркерных хромосом с последующим применением СЕР и LSI ДНК-проб. Если маркерная хромосома имеет неспецифические последовательности ДНК, то в таких случаях должны быть применены более чувствительные методы.

Кл юч е в ы е с л о в а: молекулярно-цитогенетическая диагностика, маркерная хромосома, ДНК-пробы.

Received 01.11.2015 